methods of fish-finding. He has also been studying combustion on a part-time basis in the Chemical Engineering Department of the Imperial College of Science and Technology, London. Mr. Senior has a good knowledge of French, German and Russian. He is married and has three sons.

Peabody Museum, Yale: Prof. C. O. Dunbar

Prof. Cart O. Dunbar, who will retire from the directorship of the Peabody Museum at Yale on July 1 , will then have served thirty-nine years on the faculty of Yale and sixteen years as director of the Museum. Prof. Dunbar graduated at Kansas in 1914 and obtained his Ph.D. at Yale in 1917. $\mathrm{He}$ was appointed assistant professor of historical geology at Yale in 1920 and then held various other geological appointments at the same University until he became curator of invertebrate palæontology and eventually director of the Peabody Museum. Dunbar is a palæontologist of international reputation and the author of many papers, and he has been editor of several scientific journals. His chief work concerned brachiopods and the Permian foraminifera. $\mathrm{He}$ is a Fellow of the Geological Society of London. His distinguished directorship of the Peabody Museum has been characterized by a wise nd progressive policy.

Dr. S. Dillon Ripley

Dr. S. Dillon Ripley, a member of the faculty of Yale since 1946, has been appointed director of the Peabody Museum in succession to Prof. Dunbar. Prof. Ripley is an outstanding authority on birds, particularly those of the Far East, and is president of the International Council for Bird Preservation, an organization with sections in forty-five countries. Ripley graduated at Yale in 1936 and took his Ph.D. in zoology at Harvard in 1940. He served in the Second World War with the Office of Strategic Services, and was appointed to Yale as lecturer and assistant curator of zoology in 1946 and became associate professor in 1955. He has spent the major portion of the time outside the United States in the study of bird life. In several Asiatic areas he has been the first white man seen by the local population. $\mathrm{H}_{\Theta}$ is also a distinguished writer and his works combine philosophy and literary quality with the recording of seientific facts. With such a background of experience the future of the Peabody Museum and its collections is assured.

The Argus High-altitude Geophysical Experiments

Dr. Alan T. Waterman, director of the National Science Foundation, and Dr. Detlev W. Bronk, president of the U.S. National Academy of Sciences, have issued a joint statement referring to the Argus high-altitude geophysical experiments last August and September. Reduction, analysis and ovaluation of the observations have been going on, in order to interpret those of scientific significance. Plans are well advanced for the orderly distribution to the world's scientists of appropriate scientific information, as a part of America's participation in the International Geophysical Year. As scientific papers are completed, publication will proceed through the appropriate scientific journals. In addition, plans have been made to summarize the scientific results in the course of one of the four symposia to be held at the annual meeting of the U.S. National Academy of Sciences during April 27-29.

\section{Atomic Power Station for Japan}

THE Japan Atomic Power Company has announced in Tokyo that on April 3 it had issued a letter of intent to the General Electric Co., Ltd., of England, for the construction of a 150-MW. atomic power station at Tokai-Mura, some seventy miles north-east of Tokyo. This order will be worth in the region of $£ 20,000,000$ and marks an important step forward for the General Electric Company, which has been re. organized into three main groups with the view of giving greater drive to its main activities, particularly the development of its heavy engineering and nuclear energy side. The success achieved in Tokyo has been aceompanied by several other large engineering orders during the past month, including an order for two 200-MW. turbo-generator sets for the Kincardine station of the South of Scotland Electricity Board, valued at about $£ 4,000,000$, and an order for a complete ore preparation plant for the Redbourn Works of Richard Thomas and Baldwin, Ltd., valued at about $£ 1,250,000$.

\section{Popularizing Astronomy}

THe International Geophysical Year and the launching of artificial satellites have led to a greater public awareness of scientific developments. This has created a need for the supply of accurate information in a more systematic manner than is possible in the average newspaper and with less technical detail than is appropriate even in an avowedly popular scientific magazine. The series of twelve articles which Dr. R. A. Lyttleton is contributing to the Illustrated London News is therefore especially welcome. Under the general heading, "The Universe at the Beginning of the "Space Age' ", Dr. Lyttleton has written twelve articles. The first of these appeared on February 21, and the others are being published weekly in subsequent issues. The facilities provided by the Illustrated London News through their artist, Mr. G. H. Davis, are being used to great advantage in illustrating the articles. The first two articles dealt with the Earth and terrestrial meteorite craters. The next six deal with the Sun, planets, comets and the origin of the solar system, and the last four articles will deal with the universe of stars and galaxies.

\section{Navigational Aids}

In reply to questions in the House of Commons on March 18, asking for a statement regarding the recent meeting of the International Civil Aviation Organization at Montreal, the Minister of Transport and Civil Aviation, Mr. H. Watkinson, said that, in the Government's view, present standards of safety in congested air space could not be maintained with the use of VOR-DMET, the United States system of short-range navigational aid for aireraft, without seriously reducing the efficiency of air traffic control. Although twenty of the thirty-seven countries represented at the Conference voted for the adoption of this system, the British Decca system was the only navigational aid at; present available which met the requirements of the International Federation of Air Line Pilots Association for an accurate and reliable short-range navigational aid based on the area coverage system, and designed to provide pictorial presentation of navigational information to the pilot in the cockpit. In the Government's view the Conference had not based its considerations on sound and objective grounds and the Government would continue to press for a more satisfactory 